\title{
Feedback: A Synopsis of Reader's Responses
}

I have an idea for HSM Journal. It may be a silly idea, but even if it is a good idea, nothing like it will be done. People will be afraid. Even an experimental journal cannot afford to be so daringly honest.

The idea is this: the name should be changed to 'Human Systems Management: A Forum for Half-Baked Ideas'.

The phrase 'half-baked' is a common colloquical expression, used as a casual put-down. If people stopped to think, they would realize that what the world needs is more half-baked ideas. The ideas that we do get are so well cooked, out of fear of being half-baked, that usually they are baked to a cinder.

The emphasis is on the 'half' in half-baked. I am not calling for the sort of ideas that could be captured by tape-recording an academic cocktail hour. What I mean is ideas in the process of becoming. I want a Journal where people can share their hunches and flashes of insight without fear of appearing ridiculous. The tyranny of the respectable journals is only a manifestation of a more pervasive tyranny that bullies people into keeping their most creative thoughts private. The young have their reputations to make; the old have their reputations to preserve. Safety first becomes everyone's motto.

Consider a young professor or manager who has just gotten a new idea. Ideally, he will follow where the idea leads him, fearlessly, gaining encouragement and fresh inspiration from those he shares it with. In reality, the very opposite usually occurs. He stops himself dead in his tracks. He compares his idea against the day's reigning paradigm among his tribe. He feverishly hunts for 'data' and then fiddles endlessly with $R^{2}$. He turns his back on the idea and it withers and dies.

I hope that our Journal can be a rallying point for those whose self-confidence gives them the courage to be 'unserious'. Liberated from the hypocrisy of decorum, we may say in ordinary language what is really on our minds and thereby discover what we really think. In this spirit, I have offered my suggestion.

David H. WEINFLASH

\section{ECONOGENESIS}

In the beginning Mammon created commerce and industry. And the marketplace was void and without form, and illiquidity was on the face of the balance sheet. And the spirit of Mammon moved upon the face of the income statement.

And Mammon said, "Let there be cash flow!". And there was cash flow. And Mammon saw that the cash flow was positive. And Mammon segregated the debit accounts from the credit accounts. And Mammon called the debit accounts assets, and the credit accounts He called liabilities. And there was a debit and a credit, the first quarter, unaudited.

And Mammon said, "Let there be investment in the midst of consumption, and let it separate the lenders from the borrowers", and it was so. And Mammon called the investment capital formation, and the consumption He called deficit spending. And there was a debit and a credit, the second quarter, unaudited.

And Mammon said, "Let the means of production be gathered in one place, and let imperfect competition appear!". And Mammon called the imperfect competition price-fixing and the gathering together He called monopoly. And there was a debit and a credit, the third quarter, unaudited.

And Mammon said, "Let there be economic theories in the firmament to separate the wise from the foolish, and let them be for signs and seasons". And Mammon made two great theories: the greater to rule macroeconomics and the lesser to rule microeconomics. Econometrics He also made. And Mammon saw that it was publishable. And there was a debit and a credit, the fourth quarter, unaudited.

(c) North-Holland Publishing Company

Human Systems Management 1 (1980) 93-95 
And Mammon said, "Let the market bring forth every sort of firm and enterprise that competes on the face of the earth.". The great conglomerates of the field and holding companies of the deep He made. And Mammon saw that they were cost-effective. And Mammon said, "Be fruitful and diversify!". And there was a debit and a credit, the fifth quarter, unaudited.

And Mammon said, "Let every industry bring forth its own union and regulatory agency, each after its own kind; and every sort of tax that flieth and bureaucracy that creepeth.". And Mammon saw that they were countervailing. And Mammon said, "Let Us make managerial man in Our image!". And Mammon blessed them, male and female, saying "Evaluate, coordinate, plan, and control!". And Mammon gave them dominion over all the factors of production and all the resources of the earth, fungible and unfungible. And Mammon saw everyting that He had made, and behold, it was Pareto-optimal. And there was a debit and a credit, the sixth quarter, unaudited.

And the mixed-economic system was finished, and all the participants therein. In six quarters Mammon created the real world and in the seventh, He went public.

David H. WEINFLASH

\section{ON THE FUTURE OF HUMAN ORGANISATIONS}

A.G. Kefalas' editorial "On the Future of Human Organizations: An Overview" deals with human organizations that are designed specifically to study, anticipate, influence, mold, predict, prepare for, and otherwise deal with the future. An increasing number of people are earning their livings by thinking about the future, imagining scenarios, and devising strategies that will prepare their clients or employers to thrive in the next century. Kefalas draws our attention to this latest installment in the perennial human effort to foresee the future effects of present action.

From time immemorial, there have been certain people who claim special ability to look into the future. But the modern futurologist is as far from the fortunetellers, soothsayers, and sibyls of legend as a modern medical practitioner is from a snake oil peddler. The modern futurologist will, as a rule, not attempt to predict specific events in the immediate future. Rather, he claims insight into general trends of the more distant future.

At first, it seems preposterous that someone who cannot see to the end of the year should be confident of his ability to see to the end of the century. Upon reflection, we discover the paradoxical nature of futurology: the longer our time horizon, the greater our confidence in our conclusions.

Kefalas attributes the current interest in futurology to the accelerating rates of change of nearly all aspects of society throughout the world. In earlier times, the world changed more slowly and a manager could simply heed Voltaire's advice to "tend his own garden" and let the future take care of itself. If a firm was internally sound, financially and managerially, it could be confident of weathering any future storm.

Today, with change so rapid, most businesses fail, not from internal flaws, but because they are overtaken by external events for which they were unprepared. In this environment, the futurologist seems to function as a psychiatrist to an anxious corporation whose neurotic symptom is an uncertainty about its future produced by the realization that it is no longer master of its own fate. As Kefalas sees it, the futurologist cannot be passive or neutral if he is to be useful. The futurologist doesn't merely "dream up some future ... worlds"; he exhibits "active human involvement" in steering the world toward the most desirable of futures.

In his editorial Kefalas describes in some detail the institutionalization of futurology in education, business and government. He describes "The World Future Society" with its 24000 members in 80 countries and lists its aims. However, in the last analysis, the true impact of futurology is measured by "how today's managers relate their today's actions to their future consequences". In both business and government, short-range considerations still dominate decisionmaking; the planning horizon ends with the next quarterly report or election. Are the future-related reports and studies being generated in ever more impressive numbers truly influencing policy decisions, or are the reports little more than window-dressing?

Kafalas concludes his editorial with a bold assertion: “ . . humankind is beginning to rapidly approach some limits to its organizational ability". This limit to future development does not arise from the increasing scarcity of 
dwindling natural resources. Rather it is human resources that are inadequate; Kefalas speaks of " . . a huge lack of talent for planning, designing, and managing organizations". We share his hope that $H S M$ will be instrumental in producing leaders who possess precisely this talent.

David H. WEINFLASH

A.G. Kefalas' editorial statement and D. Weinflash's comments emphasize one important point: the future is, at least to some extent, becoming malleable: it can be designed, it is within the reach of conscious human control. Modern prognosticators are not the simple (technological) forecasters of the past; they are more concerned about the ways in which the future may be altered by our actions and about the extent a desirable future course might be chosen. We have moved from primitive forecasts, predictions and prophecies, to elaborate future scenarios, designs and projects. Large numbers of people make their living by devising strategies, drawing blueprints and attempting to steer social consciousness towards a particular agenda for the future.

There is no doubt that our businesses and institutions, as well as individuals, are genuinely interested in the future. There is no doubt that the modern futurologist is beginning to play a vital role in our decision making, policy formulations and strategic planning.

Let us assume that the future is really, to a certain extent, pliable by purposeful human action. Then a flurry of questions breaks out: Who is going to design the future? For whom? Who is going to live in it? Whose values are to be taken into account? Whose values are to be suppressed? Why?

In our society, to be able to afford to deal with the future, to put forward meaningful scenarios and to be listened to as well, requires wisdom, experience, power, visibility, self-confidence, and eloquence. These are the attributes of men in their years of olden maturity. Consequently, any self-respecting scientist or public figure will be tempted to devote at least some of his or her winter years to 'designing the future' for the coming generations.

Let us assume that a typical futurologist is about sixty years old. His or her values were shaped sometimes in the forties, in response to the educational principles and ideas dominating the thirties. The fifties and the sixties were the decades of building up his or her professional and societal reputation and approval. In the early seventies, they were ready to design their first scenarios for the year 2000 and beyond . ... But should the world in the year 2000 be so prominently shaped by the values acquired during the forties?

The most active and influential inhabitants of the year 2000 were born between 1950 and 1970. They are the ones who will have to implement our future 'designs'. They are the ones who will be held responsible for the flaws in our reasoning. They are the ones who will have to explain our oversights to the generations yet to be born. Are we so grandiose as to pretend having insights into their value systems? Are we arrogant enough to shape the world while being de facto exonerated of the responsibility of living our 'designs' through?

The future can only be found in the minds and in the values, with all the contingencies for evolution and change, of those who are today in their teens, twenties, and perhaps thirties. It cannot be found in the minds or in the dreams, no matter how noble they may be, of contemporary grandfathers.

I have only one suggestion, to be taken in the spirit of self-imposed moderation: Don't design the future unless you can take the responsibility of living in it. 